\title{
Introduction: \\ A Tribute to Judy Lupart
}

\author{
Christina Rinaldi \\ University of Alberta \\ Jessica Whitley \\ University of Ottawa \\ Donna McGhie-Richmond \\ University of Victoria
}

To commemorate Dr. Judy Lupart's term as longstanding Editor and founder of the journal Exceptionality Education Canada (EEC), the Editorial Team at EEI have republished two of Judy's significant contributions to EEC. Judy founded EEC in 1991 while at the University of Calgary, and then resumed editorship in 2005 when EEC returned to Alberta, this time at the University of Alberta. Shortly after the move back west, the journal expanded its vision under the name Exceptionality Education International. We are pleased to republish Judy's feature work on inclusive education and to share her vision then $(1992,2002)$ and how it relates to the successes achieved and challenges still present decades later. Four outstanding scholars in the field of inclusive, gifted, and exceptionalities education (Nancy Hutchinson, Marion Porath, Vianne Timmons, Joanne Deppeler) reflect upon Judy's past EEC publications noting that many of her recommendations have been critical to the global advancement of inclusive education at all ecological levels (e.g., child, family, schools, government, and society) in Canada and internationally. 